\title{
Efficacy and toxicity of mitoxantrone and oral etoposide in the treatment of hormone-refractory prostate cancer: pilot study
}

\author{
Eficácia e toxicidade da mitoxantrona e etoposídeo oral no tratamento de câncer de próstata \\ hormônio-refratário: estudo piloto
}

Rafael Kaliks ${ }^{1}$, Camila Guerra², Auro Del Giglio ${ }^{3}$

\begin{abstract}
Objective: To evaluate the efficacy and toxicity of the association of mitoxantrone and oral etoposide. Methods: Twelve consecutive patients with metastatic hormone-refractory prostate cancer were treated with mitoxantrone and oral etoposide. Toxicity, response rate and response duration were assessed. Results: Partial response was observed in two patients (response duration of seven and four months) and one patient had stable disease (during four months). Mitoxantrone and oral Etoposide were well tolerated and did not affect tolerability to subsequent chemotherapy. Conclusion: Mitoxantrone and oral etoposide association is an active and well-tolerated regimen in hormone-refractory prostate cancer.
\end{abstract}

Keywords: Prostatic neoplasms/drug therapy; Neoplasm metastasis; Efficacy; Drug therapy, combination; Mitoxantrone/therapeutic use; Mitoxantrone/toxicity; Etoposide/therapeutic use; Etoposide/ toxicidade

\section{RESUMO}

Objetivo: Avaliar a eficácia e toxicidade da associação mitoxantrona e etoposídeo oral. Métodos: Doze pacientes consecutivos com câncer de próstata metastático e refratário a tratamento hormonal foram tratados com mitoxantrona e etoposídeo oral. Avaliaram-se toxicidade, taxa de resposta e duração de resposta. Resultados: resposta parcial foi observada em dois pacientes (com duração de sete e quatro meses) e um paciente teve estabilização da doença (por quatro meses). Mitoxantrona e etoposídeo oral foram bem tolerados e não afetaram tolerabilidade à quimioterapia subsequente. Conclusão: A associação mitoxantrona e etoposídeo oral é um tratamento ativo e bem tolerado por pacientes com câncer de próstata metastático refratário à hormonioterapia.

Descritores: Neoplasias da próstata/quimioterapia; Metástase neoplásica; Eficácia; Quimioterapia combinada; Mitoxantrona/uso terapêutico; Mitoxantrona/toxicidade; Etoposídeo/uso terapêutico; Etoposídeo/toxicidade

\section{INTRODUCTION}

Metastatic prostate cancer is treated with androgen deprivation therapy. Such deprivation can be achieved by surgical castration or through chemical castration with the use of luteinizing-hormone-releasing hormone (LHRH) analogs (a-LHRH). Despite an initial almost universal control of disease, eventually castration no longer prevents the progressive disease. At this stage, the disease is referred to as castration-refractory prostate cancer. The standard treatment of castrationrefractory prostate cancer consists of second-line and sometimes third-line hormone manipulation ${ }^{(1)}$, with the addition of an androgen-receptor blocker and high dose of ketoconazole, respectively. Eventually, though, the disease becomes hormone-refractory, and at this stage treatment consists of chemotherapy and bisphosphonates. Since 2004, the standard treatment for hormone-refractory disease has been docetaxel-based chemotherapy, according to two trials that showed, for the first time, a gain in overall survival ${ }^{(2,3)}$. Tolerability to docetaxel is not universal. After failure of docetaxelbased therapy, although several drugs have shown some activity against the disease, none has proved to prolong survival in randomized trials. Both mitoxantrone and etoposide have been used separately with some activity against prostate cancer. Considering the fairly mild toxicity profile, the possibility of using oral etoposide

\footnotetext{
Study carried out at Faculdade de Medicina do ABC - FMABC, Santo André (SP), Brazil.

${ }^{1} \mathrm{MD}$; Oncologist at Hospital Israelita Albert Einstein - HIAE, São Paulo (SP), Brazil.

${ }^{2} \mathrm{MD}$; Faculdade de Medicina do ABC - FMABC, Santo André (SP), Brazil.

${ }^{3}$ Full professor of Oncology at Faculdade de Medicina do ABC - FMABC, Santo André (SP), Brazil.

Corresponding author: Rafael Kaliks - Rua Dr. Mario Ferraz, 95 - apto. 111 - Jd. Europa - CEP 01453-010 - São Paulo (SP), Brazil - e-mail: rkaliks@einstein.br

Received on Feb 16, 2010 - Accepted on Jun 9, 2010
} 
and the low cost of such association, this combination was suggested in order to achieve an additive effect against prostate cancer. No trial with this association has been published to date.

\section{OBJECTIVE}

To evaluate the combination of mitoxantrone (MX) and oral etoposide (E) as treatment of hormone-refractory prostate cancer in terms of efficacy and toxicity.

\section{METHODS}

The protocol was approved by the Institutional Research Committee of Faculdade de Medicina do ABC, Santo André (SP), Brazil, and the patients signed an informed consent. Between 2005 and 2006, 12 consecutive patients with hormone-refractory metastatic prostate cancer were treated with $\mathrm{MX}+\mathrm{E}$ in a tertiary public hospital in Santo André, Brazil. Patients should have documented metastasis, adequate liver, renal and cardiac function, performance status $\leq$ 2 , life expectancy of at least three months. Patients had to interrupt treatment with androgen receptor blocker at least one month prior to initiation of $\mathrm{MX}+\mathrm{E}$ in order to eliminate the confounding response that can occur immediately after its interruption. Patients who were receiving a-LHRH continued with the medication throughout the investigational treatment. All patients had castrate testosterone levels below $30 \mathrm{ng} / \mathrm{ml}$.

Since during the trial the production of oral etoposide was discontinued, the accrual of new patients had to be interrupted.

Patient characteristics are shown in chart 1.

MX was administered at $5 \mathrm{mg} / \mathrm{m}^{2}$ on days 1 and 8 , every 21 days (maximum cumulative dose of $140 \mathrm{mg}$ / $\mathrm{m}^{2}$ ) and oral etoposide $50 \mathrm{mg}$ daily, from day 1 through day 14 , every 21 days. Only one patient had received
Chart 1. Patients' characteristics

\begin{tabular}{ll|}
\hline Characteristics & \\
\hline Median age (years) & $69(55-75)$ \\
Bone metastasis & $12(100 \%)$ \\
Soft tissue metastasis & $6(50 \%)$ \\
Patients with prior chemotherapy treatment & 1 \\
Prior hormone treatment (median) & $3(1-3)$ \\
Time since diagnosis of metastasis (median) & 33 months $(4-56)$ \\
\hline $\mathrm{n}=12$.
\end{tabular}

prior chemotherapy (docetaxel) and had progressive disease. In addition to the chemotherapeutic regimen, all patients received monthly zoledronic acid due to existing bone metastasis.

Response was assessed at every cycle with PSA, alkaline phosphatase and clinical evaluation. Unless there was a biochemical or clinical suggestion of disease progression, computer tomography or magnetic resonance imaging tests were repeated every three months and bone-scans every six months. Response was classified according to the Prostate-Specific Antigen Working Group (PCWG1) criteria $^{(4)}$ in progressive measurable disease, progressive bone metastasis, stable metastases and rising PSA and rising PSA with no other evidence of metastatic disease. Toxicity was classified according to the National Cancer Institute (NCI) Common Toxicity Criteria v3.1 (grading toxicity by organ systems and scores of intensity 1 to 5$)^{(5)}$.

\section{RESULTS}

Table 1 outlines results and toxicity. With a median follow-up of 11 months (4 to 31), the median number of cycles received was 4 (2-8). Two patients achieved partial response associated with significant pain control for seven and four months, respectively, and one patient achieved stable disease during four months. Median survival for the 12 patients was 17 months. Seven patients received subsequent chemotherapy (five with

Table 1. Response and toxicities

\begin{tabular}{|c|c|c|c|c|c|}
\hline Age (years) & Site of metastases & Number of cycles & Toxicity (grade) & Best response & TTP (months) \\
\hline 55 & B & 3 & - & PD & 2 \\
\hline 57 & $\mathrm{~B} / \mathrm{ST}$ & 2 & $\operatorname{Re}(3)$ & PD & 2 \\
\hline 69 & $\mathrm{~B} / \mathrm{ST}$ & 2 & $\operatorname{Re}(3)$ & PD & 2 \\
\hline 63 & $\mathrm{~B} / \mathrm{ST}$ & 8 & $\mathrm{Ca}(2)$ & PR & 7 \\
\hline 74 & $\mathrm{~B} / \mathrm{ST}$ & 4 & - & PD & 2 \\
\hline 75 & B & 4 & $\mathrm{He}(4)$ & PD & 2 \\
\hline 75 & B & 2 & - & PD & 2 \\
\hline 67 & B & 3 & - & PD & 2 \\
\hline 71 & B & 2 & $\mathrm{He}(3)$ & PD & 2 \\
\hline 71 & B & 6 & $\mathrm{He}(4)$ & SD & 4 \\
\hline
\end{tabular}


docetaxel-based regimens) and three patients achieved partial responses.

The association $\mathrm{MX}+\mathrm{E}$ was well tolerated. Four patients developed grade 3 or 4 hematologic toxicity and required dose reduction. One patient had grade 2 cardiac toxicity and two patients had grade 3 renal toxicity, all of which improved to baseline. No patient died as a consequence of toxicity. Five patients did not present any grade of toxicity.

\section{DISCUSSION}

Although the number of patients in this pilot study is small, three patients out of 12 clearly derived significant benefit from $\mathrm{MX}+\mathrm{E}$. No studies with this combination have been published to date, therefore no comparison is possible. Considering the acceptable toxicity profile, this combination is considered a valid alternative to be added to the array of regimens that have moderate effect on hormone-refractory disease. One patient who had progressive disease on docetaxel received $\mathrm{MX}+\mathrm{E}$ and achieved a partial response lasting four months. On the other hand, out of the seven patients who subsequently received docetaxel-based chemotherapy, three had partial responses, suggesting that there is no detrimental tolerability to what would be considered to be the standard therapy. The median overall survival of 17 months is in line with the expected survival for this patient population. Although docetaxel-based chemotherapy is the standard, its tolerability is not universal and alternative less toxic regimens are frequently required. Of note is the low cost of the $\mathrm{MX}+\mathrm{E}$ regimen, of about a sixth the cost of docetaxelbased treatment. The recent finding of significant activity of abiraterone, a CYP17 inhibitor (an important enzyme in the synthesis of androgens), in patients who had failed castration ${ }^{(6)}$ and even in patients whose treatment with docetaxel failed, raises again the issue of the persistent role of the androgen receptor in signaling pathways that lead to disease progression even in a socalled hormone-refractory state. It again challenges the nomenclature of hormone-refractory disease, and raises the possibility that hormone manipulation may be intercalated between chemotherapy treatments due to both its efficacy and the chance of ensuring chemotherapy-free periods of active treatment.

\section{CONCLUSION}

$\mathrm{MX}+\mathrm{E}$ is well tolerated and leads to partial responses in hormone-refractory disease. It does not seem to impair tolerability to subsequent taxane-based therapy. MX+E can be considered a treatment option for patients with hormone-refractory prostate cancer.

\section{REFERENCES}

1. Miyake $\mathrm{H}$, Hara I, Eto H. Clinical outcome of maximum androgen blockade using flutamide as second-line hormonal therapy for hormone-refractory prostate cancer. BJU Int. 2005;96(6):791-5.

2. Petrylak DP, Tangen CM, Hussain MH, Lara PN Jr, Jones JA, Taplin ME, et al. Docetaxel and estramustine compared with mitoxantrone and prednisone for advanced refractory prostate cancer. N Engl J Med. 2004;351(15):1513-20.

3. Tannock IF, de Wit R, Berry WR, Horti J, Pluzanska A, Chi KN, et al. Docetaxel plus prednisone or mitoxantrone plus prednisone for advanced prostate cancer. N Engl J Med. 2004;351(15):1502-12.

4. Bubley GJ, Carducci M, Dahut W, Dawson N, Daliani D, Eisenberger M, et al. Eligibility and response guidelines for phase II clinical trials in androgenindependent prostate cancer: recommendations from the Prostate-Specific Antigen Working Group. J Clin Oncol. 1999;17(11):3461-7. Erratum in: J Clin Oncol. 2007;25(9):1154.

5. National Cancer Institute. Cancer Therapy Evaluation Program - CTEP. Common Terminology Criteria for Adverse Events (CTCAE) v3.0. [cited 2010 Apr 20]. Available from: http://ctep.cancer.gov/reporting/ctc.html.

6. Attard G, Reid AH, Yap TA, Raynaud F, Dowsett M, Settatree S, et al. Phase I clinical trial of a selective inhibitor of CYP17, abiraterone acetate, confirms that castration-resistant prostate cancer commonly remains hormone driven. J Clin Oncol. 2008;26(28):4563-71. Epub 2008 Jul 21. 